Metallophysics and Advanced Technologies

металофіз. новітні технол.

Metallofiz. Noveishie Tekhnol.

2020 , vol. 42, No. 3, pp. 401-414

https://doi.org/10.15407/mfint.42.03.0401

Reprints available directly from the publisher

PHYSICS OF STRENGTH AND PLASTICITY

PACS numbers: 61.66.Dk, 62.20.Qp, 81.40.Cd, 81.40.Ef, 81.65.-b, 81.70.Bt

\title{
Hardness Uniformity in AISI 4140 Using Spray Quenching Method
}

\author{
Mochamad Achyarsyah and Poppy Puspitasari ${ }^{*, * *}$ \\ Bandung Polytechnic of Manufacturing, Foundry Department, \\ 21 Kanayakan Str., \\ ID-40135 Bandung, West Java, Indonesia \\ "State University of Malang, Mechanical Engineering Department, \\ 5 Semarang Str., \\ ID-65145 Malang, East Java, Indonesia \\ "State University of Malang, \\ Centre of Advanced Materials for Renewable Energy, \\ 5 Semarang Str., \\ ID-65145 Malang, East Java, Indonesia
}

Bucket teeth are a part of the coal process circuit in bucket excavator machine. It is used to dredge the overburden or a piece of the land that covers coal piles. Bandung Polytechnic of Manufacturing produces the product with AISI 4140 steel. The problem with batch production is that it has a wide variety of hardness as the result of using a quenching by blower. Therefore, there needs an alternative to a thinner hardness of bucket teeth. This research explores the possibility of using spray quenching method. The method uses the spray to quench the samples on the rotated concrete steel shelf evenly. The Shore scleroscope hardness test performs three times on the products at two points: the tip and $80 \mathrm{~mm}$ from the tip. The results are averaged later on. They show that spray quenching produced a thinner hardness variety compared to the blower product. Product using blower has the hardness of 25.16 HRB at point 1 and 15.66 $H R B$ at point 2. Product with the first spray quenching has the hardness of 15.1 $H R B$ at point 1 and 11.56 $H R B$ at point 2 , and after the second spray quenching became 7.3 $H R B$ at point 1 and 8.4 $H R B$ at point 2. Thus, spray quenching provides a more uniform hardness along the teeth and can be a substitute for the traditional quenching method.

Corresponding author: Mochamad Achyarsyah

E-mail: achyarsyah@polman-bandung.ac.id

Citation: Mochamad Achyarsyah and Poppy Puspitasari, Hardness Uniformity in AISI 4140 Using Spray Quenching Method, Metallofiz. Noveishie Tekhnol., 42, No. 3: 401414 (2020), DOI: 10.15407/mfint.42.03.0401. 
Key words: spray quench, blower quench, hardness, product batch.

Досліджено характеристики міцності зубців ковша екскаватора, який використовують у вугледобуванні. Екскаватор використовують для розкриття поверхні або зняття шматків грунту, що покривають вугільні родовища. Зубці ковша екскаватора виготовлені на Бандунгському політехнічному заводі зі сталі AISI 4140. У процесі серійного виробництва виникла проблема, що полягала у широкому діапазоні величини твердості внаслідок використання гартування продувкою. Тому потрібний був пошук альтернативного методу для забезпечення вужчого діапазону твердості зубців ковша. Для цього вивчена можливість застосування метода гартування розпилюванням. У проведених дослідженнях використано метод рівномірного розпилювання на зразки, розташовані на обертовій сталевій полиці. Вимірювання твердості проводили тричі за допомогою склероскопа Шора на зразках у двох точках: на кінцях зубців ковша та на відстані 80 мм від кінців. Далі знаходили середнє значення результатів вимірювань. Одержані результати показали, що гартування розпилюванням дає вужчий діапазон твердості порівняно з гартуванням продувкою. Вироби з використанням продувки мали твердість 25,16 HRB в точці 1 і $15,66 H R B$ в точці 2. Вироби з використанням первинного гартування розпилюванням мали твердість $15,1 H R B$ в точці 1 і 11,56 HRB в точці 2, а після вторинного гартування розпилюванням $-7,3 H R B$ у точці 1 та $8,4 H R B$ у точці 2 . Таким чином, гартування розпилюванням дозволяє одержати більш рівномірну твердість уздовж зубців і може стати заміною для традиційного методу гартування.

Ключові слова: гартування розпилюванням, гартування з продувкою, твердість, серійне виробництво.

Исследованы прочностные характеристики зубьев ковша экскаватора, используемого при добыче угля. Экскаватор используют для вскрытия поверхности или выемки грунта, которые прикрывают угольные месторождения. Зубья ковша экскаватора изготовлены Бандунгским политехническим заводом из стали AISI 4140. В процессе серийного производства возникла проблема, связанная с широким разбросом значений твёрдости вследствие использования закалки продувкой. Поэтому возникла необходимость поиска альтернативного метода для обеспечения более узкого диапазона разброса твёрдости зубьев ковша. Для этого была изучена возможность использования метода закалки зубьев путём распыления. В проведённых исследованиях использовали метод равномерного распыления на образцы, расположенные на вращающейся стальной полке. Измерение твёрдости проводили трижды склероскопом Шора на образцах в двух точках: на концах зубьев ковша и на расстоянии 80 мм от концов. Затем определяли среднее значение результатов измерений. Проведённые исследования показали, что закалка распылением даёт меньший разброс твёрдости по сравнению с закалкой с продувкой. Полученные изделия с использованием продувки имели твёрдость $25,16 \mathrm{HRB}$ в точке 1 и 15,66 $H R B$ в точке 2. Изделия с использованием первичной закалки распылением имели твёрдость $15,1 \mathrm{HRB}$ в точке 1 и $11,56 \mathrm{HRB}$ в точке 2 , а после вторичной закалки распылением - 7,3 HRB в точке 1 и $8,4 H R B$ в точке 2. Таким образом, закалка распылением обеспечивает получение более 
равномерной твёрдости вдоль зубцов и может стать заменой для традиционного метода закалки.

Ключевые слова: закалка распылением, закалка с продувкой, твёрдость, серийное производство.

(Received March 15, 2019)

\section{INTRODUCTION}

To compete in the casting industry, manufacturers have to create products with good quality and competitive price suitable for the consumers' needs. An effective, efficient, and optimize process becomes important to eliminate waste during the production process [1]. Bandung Polytechnic of Manufacturing already produced standardized batches of bucket teeth with AISI 4140 from HSLA, or low steel alloys with high strength, as used in the coal industry particularly in PT Bukit Asam. However, there was non-uniformity of hardness in the products. The non-uniformity caused different qualities in the product batch [2].

Figure 1 displays the nose diagram of AISI 4140 CCT (Continuous Cooling Transformation) using blower quench at Bandung Polytechnic of Manufacturing [3]. The method caused a wide variety of hardness and a slower cooling compared to water or oil method $[2,4]$.

There needed another method, apart for the blower method but at a similar cooling rate, to produce a batch with uniform hardness. The

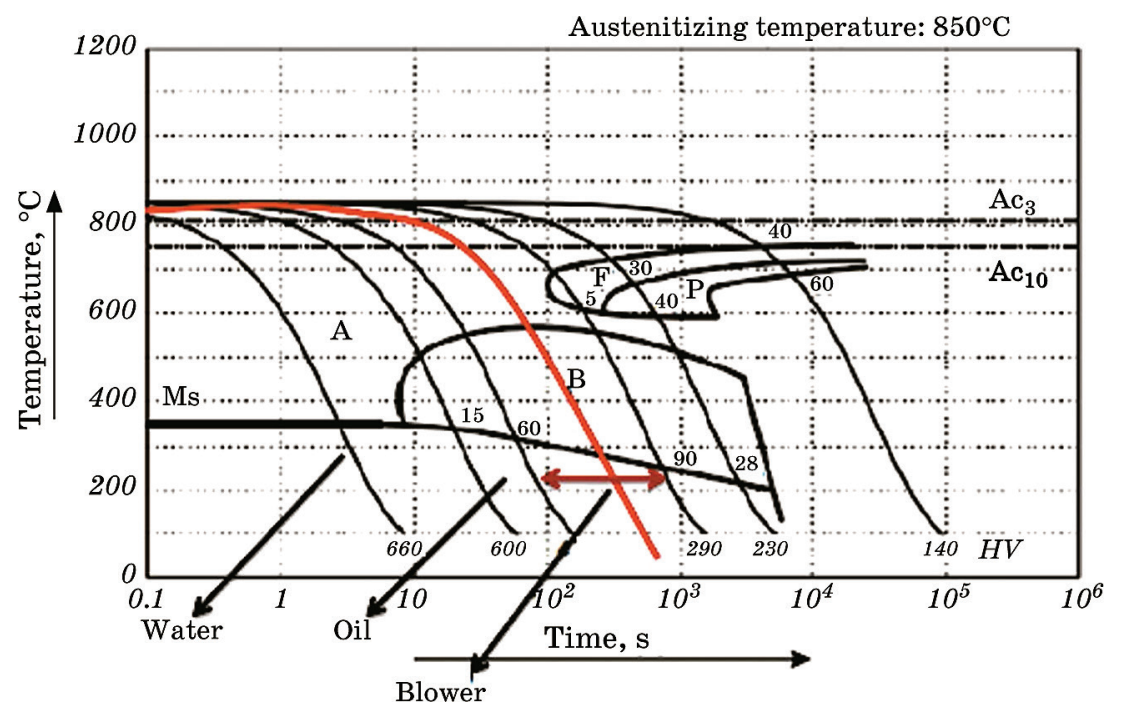

Fig. 1. AISI 4140 CCT diagram [3]. 
method used in this research was spray quenching [5]. Spray quenching terminology refers to a variety of quenching, a heat transfer by bumping the heated surface with quench medium [6]. All quench processes varied on the turbulence degree, e.g., adding gas to the water points or other volatile liquids to spray in the fog quenches process. This research conducted and controlled the cooling process in several trials. However, there were two main problems of spray quenching, such as hardness similarity between spray quenching and blower quenching methods also how both method compared on uniformity of hardness.

The hardness test used shore scleroscope hardness test as the ASTM A448 standardized test, with the working principle of dropping diamonds from a fixed height to the surface of the test object. The potential energy changes into kinetic energy at the point on the object. The point will undergo plastic deformation so that half the energy is absorbed for the deformation. The absorbed energy bounces back into the energy that bounces the indenter [7].

Spraying distance and water pressure influenced the spray quenching process (Fig. 2) [8]. The spraying distance, be it horizontal or vertical, affected the droplet size and thus influenced the cooling rate. The spray quenching method also required constant water pressure to prevent the Leidenfrost effect. Hence this research used the device from Nilfisk C110-3-5 X-TRA type [9].

\section{EXPERIMENTAL DETAILS}

This research's success rate depended on the steps taken. Formulating

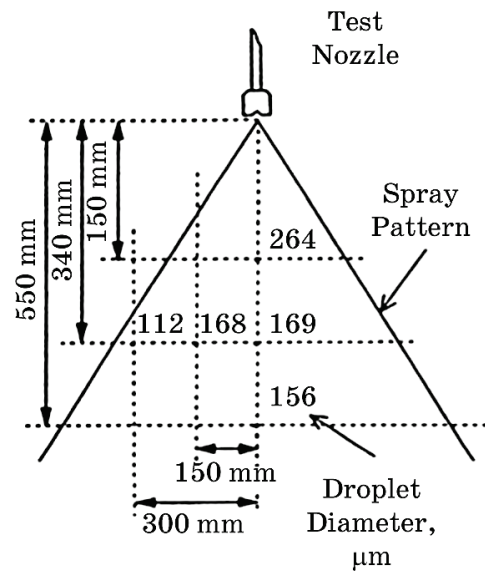

$a$

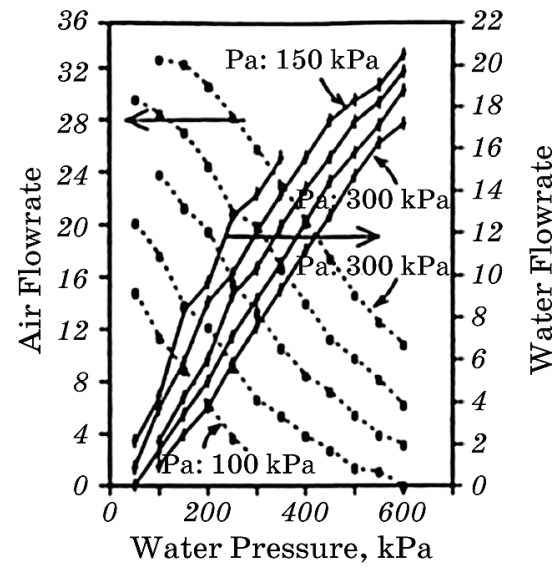

$b$

Fig. 2. Droplet size and water pressure diagram [8]. 
the problem took place first before formulating the clear and systematic steps and problem-solving methods [5].

This research started with literature studies, process planning, and determining the number of samples [10]. The starting point to compare the hardness and cooling rate was the existing blower process. Then, the research moved into the $n^{\text {th }}$ quenching process to obtain a comparison and conclusions. The changing variable from quenching spray was the distance variables, both vertically and horizontally [11].

The spray quenching process used a specific device from Nilfisk C110-3-5 X-TRA using normal pressure 7.5 MPa (75 bar), maximum pressure $11 \mathrm{MPa}$ (110 bar), maximum temperature $40^{\circ} \mathrm{C}$, AC power $230 / 240 \mathrm{~V}-1 \mathrm{~kW}$, and maximum debit (out) 5.2 litre/minute.

\section{RESULTS AND DISCUSSION}

This section discusses the conducted processes and the hardness test results from the blower existing, spray quenching 1 and spray quenching 2 processes.

\subsection{Heat Treatment}

Taken from the [3] heat treatment for the AISI 4140 material consists of normalizing, annealing, tempering, and spheroidizing. This research only conducted normalizing and hardening [2].

Normalizing the product aimed to uniform the matrix to create a smooth particle after hardening. Also, generally on as-cast products, a

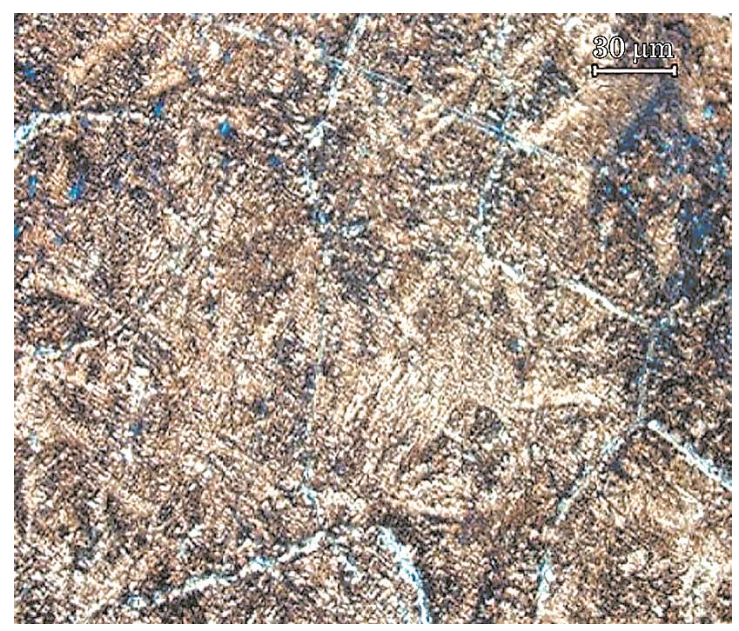

Fig. 3. As-cast microstructure. 
Widmanstätten pattern is often found that makes the product fragile, which is why it needs a normalizing process [12].

The recommended temperature from the book for the normalizing process is around $840-900^{\circ} \mathrm{C}$ and the recommended temperature for hardening is $830-870^{\circ} \mathrm{C}$. Because the maximum hardening temperature is in the normalizing range, to simplify, this research used $870^{\circ} \mathrm{C}$ both for normalizing and hardening with 4 hours of holding time. Figure 3 displays an image of the as-cast while Fig. 4 displays the metal microstructure after normalizing [13].

The hardness value after normalizing dropped although the toughness increased due to the finer structure. The next process was hardening to increase the hardness value. Figure 5 illustrates the comparison

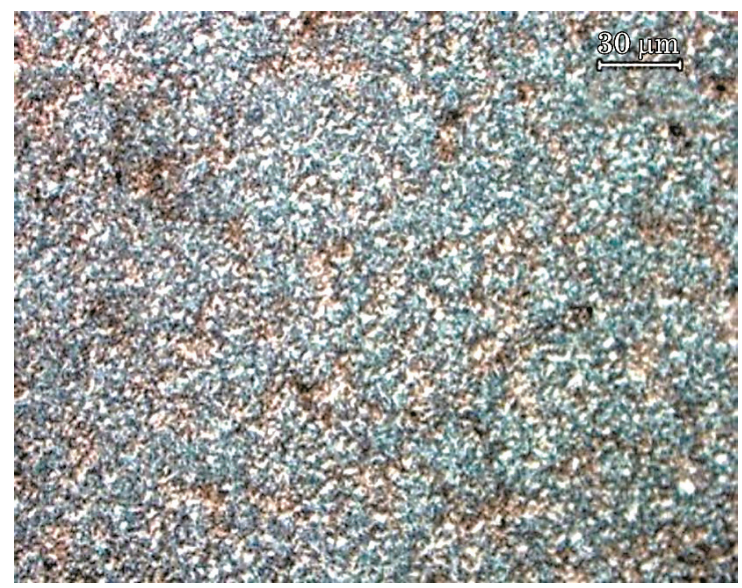

Fig. 4. Normalizing microstructure.

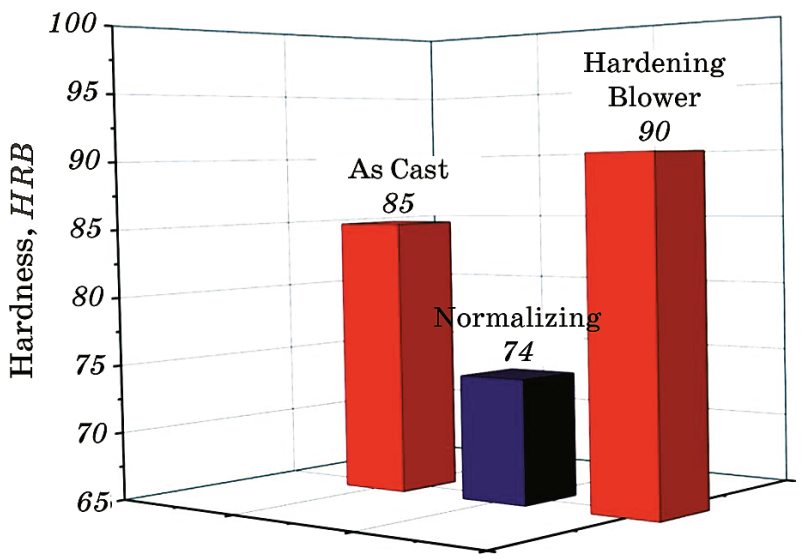

Fig. 5. Histogram of as-cast, normalizing, and hardening hardness values. 
of the hardness of as-cast, normalizing, and hardening products as a reference for the hardening process after normalizing [14].

\subsection{Hardness Test}

This research carried out the hardness test at two points: at the tip and $80 \mathrm{~mm}$ from the tip. Figure 6 presents two points. Each point was administered three tests and then averaged [7].

The hardness test operation plan started from the sample numbering then smoothened the objected area. The samples were the base for the testing device. The next process was measuring the testing distance, testing, and logging the data before processing.

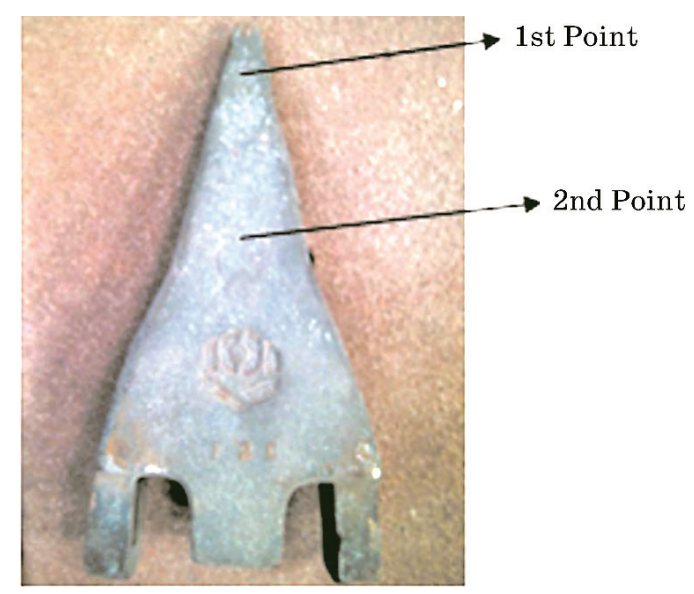

Fig. 6. Positions of tested points.

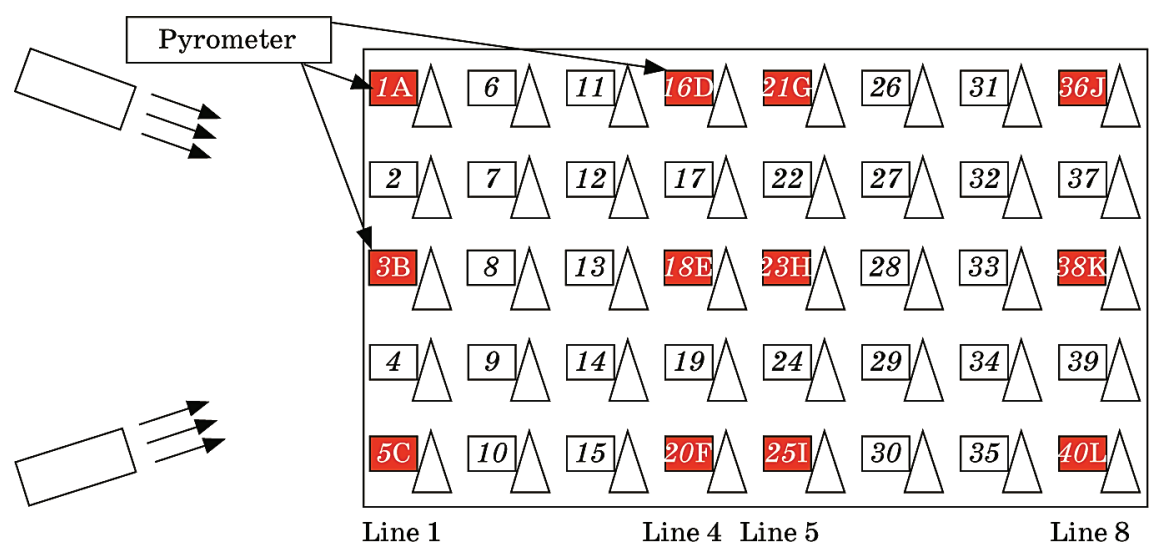

Fig. 7. The existing blower layout. 
The existing blower process was conducted at $870^{\circ} \mathrm{C}$ with 4 hours holding time. This process used two blowers at the front to blow the air. There were 12 out of 40 samples, marked in red, was measured with a pyrometer as displayed by Fig. 7 .

Figure 7 depicts the layout from the production of batch bucket teeth with AISI 4140 material in Bandung Polytechnic of Manufacturing workshop. Because the air distance to each line was different, it caused a relatively higher cooling rate on the front compared to areas farther away from the blower, thus causing a wide range of hardness

TABLE 1. Hardness test results from the existing blower.

\begin{tabular}{cc}
\hline Hardness number $(H R B)$ from existing blower* \\
\hline AVG & 85.5 \\
Range & $71.2-96.4$ \\
W & 25.2 \\
\hline
\end{tabular}

"Information: AVG (average), W (lowest-highest value).

TABLE 2. Cooling rate and hardness value from the existing blower process.

\begin{tabular}{c|c|c|c}
\hline Sample & $\begin{array}{c}\text { Cooling rate, } \\
{ }^{\circ} \mathrm{C} / \mathrm{s}\end{array}$ & $\begin{array}{c}\text { Hardness number }(H R B) \\
\text { at 1-st point }\end{array}$ & $\begin{array}{c}\text { Hardness number }(H R B) \\
\text { 2-nd point }\end{array}$ \\
\hline 1A & 0.70 & 96.4 & 87.2 \\
3B & 0.59 & 90.7 & 83.3 \\
5C & 0.56 & 95.5 & 84.1 \\
16D & 0.51 & 93.3 & 84.9 \\
18E & 0.50 & 80.3 & 76.8 \\
20F & 0.55 & 86.3 & 79.8 \\
21G & 0.56 & 87.0 & 98.9 \\
23H & 0.45 & 83.0 & 81.3 \\
25I & 0.52 & 82.4 & 75.9 \\
36J & 0.52 & 78.6 & 69.9 \\
38K & 0.52 & 72.8 & 75.9 \\
40L & 0.46 & 76.3 & \\
\hline
\end{tabular}

TABLE 3. Frame design scoring**.

\begin{tabular}{c|c|c|c|c|c}
\hline No & Material type & Machinability & Surface area & Strength & Total \\
\hline Design 1 & 1 & 1 & 1 & 3 & 6 \\
Design 2 & 2 & 2 & 1 & 2 & 7 \\
Design 3 & 2 & 2 & 1 & 2 & 7 \\
Design 4 & 3 & 3 & 3 & 1 & 10 \\
\hline
\end{tabular}

***Information: 1 (bad), 2 (adequate), 3 (good). 
values. Table 1 presents the results of the hardness testing data on the existing blower process and Table 2 - the results of hardness testing with the cooling rate on 12 samples [15].

There were four frame designs, but only the best was applied. Table 3 states that design number 4 was the best design to use (Fig. 8). The spraying was conducted in rotary or rotated in the hope that the object's surface would be sprayed evenly by the droplets as shown at Fig. 9.

This research used horizontal and vertical spraying. However, the further the nozzle from the object resulted in smaller droplets and a more distributed water debit compared to closer distance. Thus, this

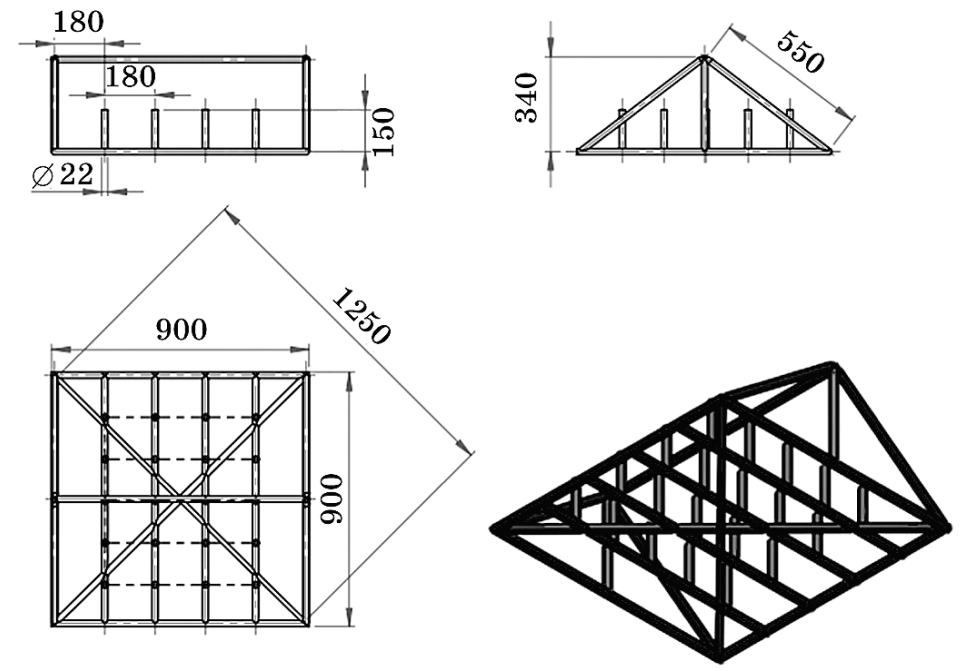

Fig. 8. Design number 4 .

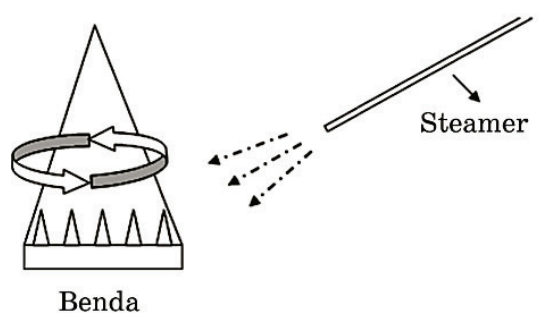

$a$

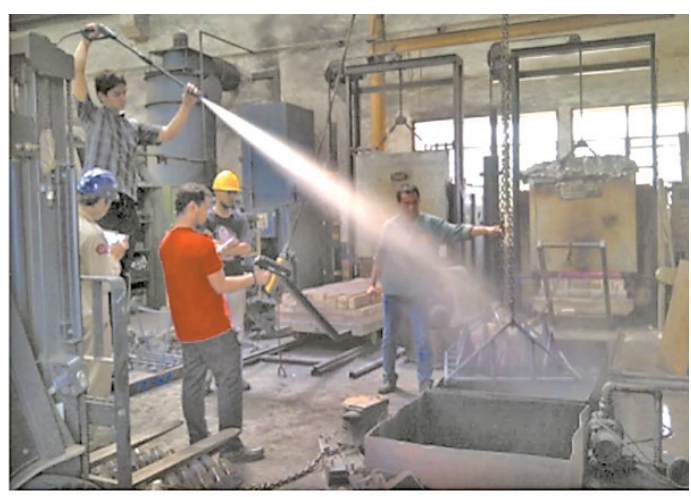

$b$

Fig. 9. Spraying method. 
research determined the distance as below (Fig. 10): spray quenching 1: 3 meter horizontal and 2.5 meters vertical; spray quenching 2 : 1.5 meter horizontal and 2 meters vertical.

\subsection{Spray Quenching Process}

Figure 11 explains the spray quenching process. Twelve out of 20 samples were marked to observe the cooling process. The samples had been administered normalizing and hardening process with holding time of 4 hours at $870^{\circ} \mathrm{C}$ then administered spray quenching. The 20 samples were divided into four lines or area that represented the cooling rate of the conducted spray.

Table 4 explains the hardness test and cooling rate from spray 1 and 2. Table 4 shows that the hardness ranges from $T 1$ (the tipping point) is $15.1 \mathrm{HRB}$ and $11.56 \mathrm{HRB}$ at T2 (80 $\mathrm{mm}$ from $T 1)$. Thus, the hardness variety was thinner compared to the blower process. After measurements with a pyrometer, the cooling rate using the spray quenching process was faster with more uniform hardness. However, to obtain comparative data on the spray process, the second spray process was

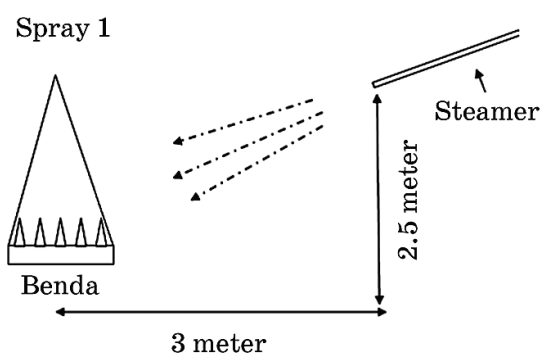

$a$

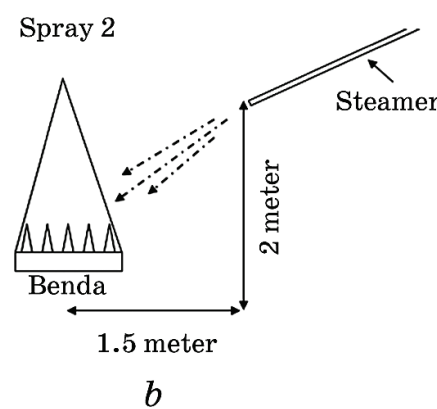

b

Fig. 10. Spray quenching 1 and 2.

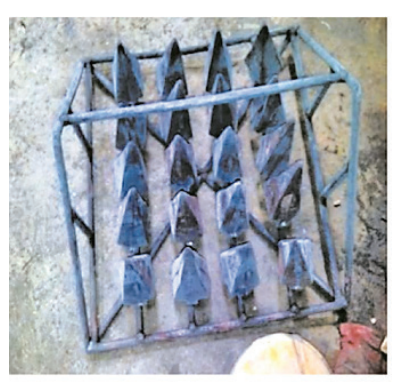

$a$

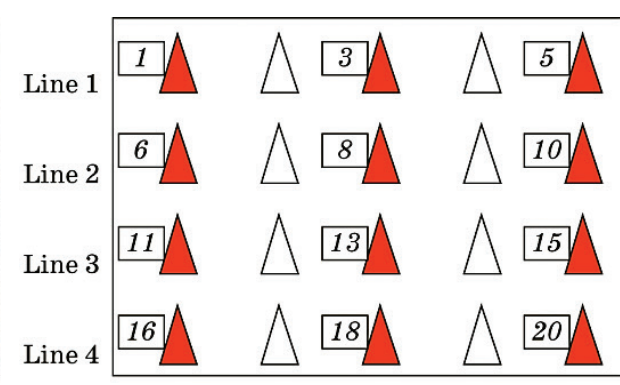

$b$

Fig. 11. Spray quenching layout. 
carried out to see the distance function to the hardness and distribution $[8,16]$.

Table 5 shows that the average hardness value increases compared to the spray quenching 1 process, which is $91.6 \mathrm{HRB}$ at point 1 and 92.4 $H R B$ at point 2. Likewise, the range of hardness produced is leaner for point 1 that is $7.3 \mathrm{HRB}$ and for point 2 that is $8.4 \mathrm{HRB}$. Table 5 presents, which the cooling rate using this process is greater than the previous processes. The spray quenching 2 processes had a leaner range of hardness than quenching 1 spray so that it could be used as comparative data for the blower process and spray quenching 1 process in terms of hardness, cooling rate, and distribution $[8,16]$.

TABLE 4. Spray 1 cooling rate.

\begin{tabular}{c|c|c|c}
\hline Sample & $\begin{array}{c}\text { Cooling rate, } \\
{ }^{\circ} \mathrm{C} / \mathrm{s}\end{array}$ & $\begin{array}{c}\text { Hardness number }(H R B) \\
\text { at 1-st Point }\end{array}$ & $\begin{array}{c}\text { Hardness number }(H R B) \\
\text { 2-nd Point }\end{array}$ \\
\hline 1 & 1.53 & 97.1 & 88.6 \\
3 & 1.46 & 93.0 & 89.3 \\
5 & 1.37 & 90.9 & 84.6 \\
6 & 1.23 & 82.6 & 81.5 \\
8 & 1.28 & 88.4 & 83.7 \\
10 & 1.16 & 89.3 & 85.7 \\
11 & 1.21 & 86.3 & 85.7 \\
13 & 1.19 & 91.9 & 83.1 \\
15 & 1.15 & 84.7 & 87.1 \\
16 & 1.31 & 88.8 & 86.4 \\
18 & 1.00 & 88.7 & 87.1 \\
20 & 1.11 & 90.0 & 88.7 \\
\hline
\end{tabular}

TABLE 5. Spray 2 cooling rate.

\begin{tabular}{c|c|c|c}
\hline Sample & $\begin{array}{c}\text { Cooling rate, } \\
{ }^{\circ} \mathrm{C} / \mathrm{s}\end{array}$ & $\begin{array}{c}\text { Hardness number }(H R B) \\
\text { at 1-st point }\end{array}$ & $\begin{array}{c}\text { Hardness number }(H R B) \\
\text { 2-nd point }\end{array}$ \\
\hline 1 & 1.67 & 94.6 & 93.1 \\
3 & 1.70 & 88.9 & 90.9 \\
5 & 1.68 & 94.9 & 91.6 \\
6 & 1.64 & 90.3 & 96.2 \\
8 & 1.55 & 94.0 & 92.4 \\
10 & 1.56 & 95.6 & 91.8 \\
11 & 1.53 & 94.8 & 93.6 \\
13 & 1.49 & 94.9 & 97.2 \\
15 & 1.41 & 88.9 & 92.4 \\
16 & 1.37 & 94.0 & 91.1 \\
18 & 1.38 & 90.3 & 90.3 \\
20 & 1.35 & 88.9 & 92.1 \\
\hline
\end{tabular}




\subsection{Comparison of Hardness Value}

After testing the hardness, the entire samples that had been tested from the three processes were compared and seen through the scatter diagram. The following diagram illustrates the distribution of the three processes (Fig. 12).

The Scatter diagram describes the distribution of data in the samples, in this case, to compare the range of hardness. Figure 13 is a stock diagram created by the researcher, the $Y$-axis shows information from sample hardness in $H R B$ units, and $X$-axis is the information from sample numbers 1 to 20 .

The red arrow shows the hardness range at point 1 . The first arrow

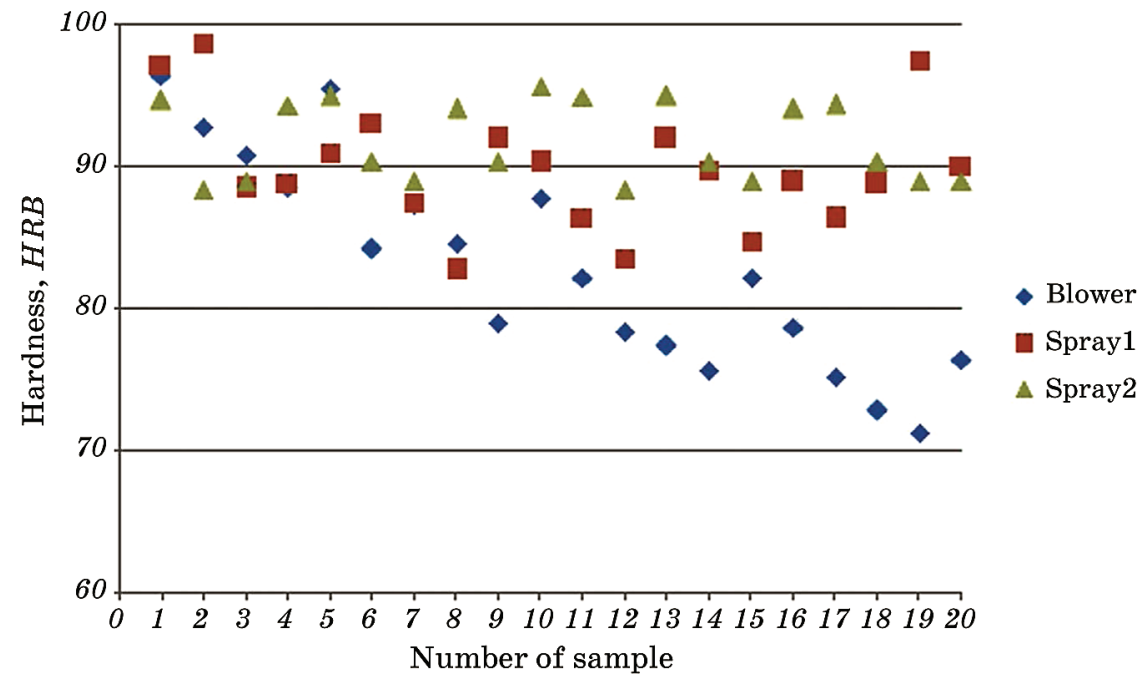

Fig. 12. Scatter diagram from the three processes.
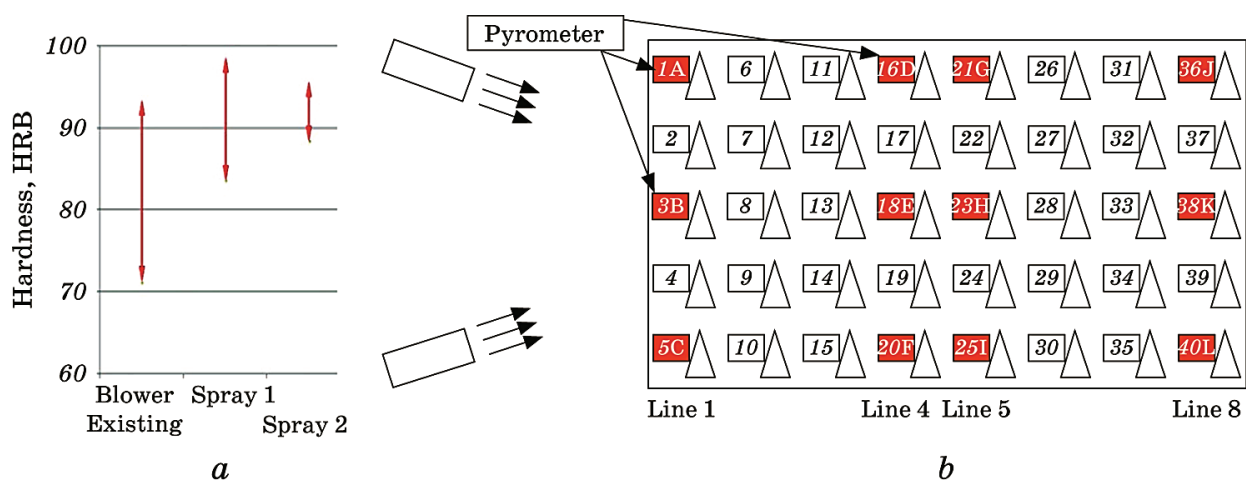

Fig. 13. Comparison diagram of blower existing and spray quenching method. 
shows the range of the existing blower process with the hardness of 25.16 $H R B$ and the average hardness of 85.46 HRB. The second arrow line shows the spray quenching 1 with the hardness range of $15.1 \mathrm{HRB}$ and the average hardness is $89.82 H R B$. The third arrow shows the spray quenching 2 with the hardness range of $7.3 \mathrm{HRB}$ and hardness average of 91.6 HRB. The spray quenching process made a thinner hardness compared to the existing blower process. Besides, the varied distance in the spray 1 and 2 processes influenced higher hardness value because of the faster cooling rate $[4,11]$.

\section{CONCLUSION}

The hardening process of batch production at the Bandung State Polytechnic Manufacturing through a spray quenching process produces a smaller hardness range and a higher average hardness value than the hardening method using a blower.

The spraying distance during the spray quenching process affected the range and value of hardness with the result of $15.1 \mathrm{HRB}$ at point 1 and $11.56 \mathrm{HRB}$ at the point 2 from the spray 1 to $7.3 \mathrm{HRB}$ at point 1 and 8.3 $H R B$ at point 2 after the second quenching spray.

The research data showed that the closer the spraying distance resulted in the higher heat transfer and hardness as well as a thinner distribution of hardness values.

\section{REFERENCES}

1. S. Shahria and S. Wiengwiset, Appl. Clay Sci., 67-68: 26 (2012).

2. K. M. Zwilsky and E. L. Langer, ASM Metals Handbook, Technology (ASM International: 2001), vol. 1.

3. ASM Handbook, Properties and Selection: Irons, Steels, and High-Performance Alloys (ASM International: 1990), vol. 1.

4. W. Callister and D. Rethwisch, Materials Science and Engineering: an Introduction (ASM International: 2015).

5. ASM Handbook: Heat Treating, Technology (ASM International: 2001), vol. 4.

6. N. Mascarenhas and I. Mudawar, Int. J. Heat Mass Transfer, 53, Iss. 25-26: 5871 (2010).

7. D. Tumac, Rock Mech. Rock Eng., 47: 703 (2014).

8. George E. Totten, C. E. Bates, and N. A. Clinton, Handbook of Quenchants and Quenching Technology (ASM International: 1993), ch. 7.

9. N. Mascarenhas and I. Mudawar, Int. J. Heat Mass Transfer, 55, Iss. 11-12: 2953 (2012).

10. S. Suryana, U. Sekaran, S. Lee, T. Stearns, and G. M. Geoffrey, Int. J. Manage., 3: 1 (2013).

11. Michael Ashby and Kara Johnson, Materials Design (Butterworth-Heinemann: 2003). 
12. George E. Totten, Steel Heat Treatment Handbook (ASM International: 2006).

13. ASM Handbook: Heat Treatment (ASM International: 1991), vol. 4.

14. S. Coriell, Precipitation Hardening of Metal Alloys (A Century of Excellence in Measurements, Standards, and Technology: 2000).

15. G. Liang and I. Mudawar, Int. J. Heat and Mass Transfer, 115: 1206 (2017).

16. X. Deng and D. Ju, Phys. Procedia, 50: 368 (2013). 